九州大学学術情報リポジトリ

Kyushu University Institutional Repository

\title{
The Effect of Feeding Level on Growth and Feed Conversion in Silver Sea Bream, Spar-us sarba
}

Mihelakakis, Apostolos

Fishery Research Laboratory, Faculty of Agriculture, Kyushu University

Kitajima, Chikara

Fishery Research Laboratory, Faculty of Agriculture, Kyushu University

https://doi.org/10.5109/24062

出版情報: 九州大学大学院農学研究院紀要. 39 (1/2)，pp.9-14，1994-12. Kyushu University バージョン：

権利関係 : 
J. Fac. Agr., Kyushu Univ., 39 (1•2), 9-14 (1994)

\title{
The Effect of Feeding Level on Growth and Feed Conversion in Silver Sea Bream, Spar-us sarba*
}

\author{
Apostolos Mihelakakis and Chikara Kitajima \\ Fishery Research Laboratory, Faculty of Agriculture, \\ Kyushu University, Fukuoka 811-33, Japan \\ (Received June 9, 1994)
}

\begin{abstract}
A 40-day experiment was conducted to determine the effects of feeding level on growth and feed conversion efficiency in silver sea bream with an average initial body weight of 86 g. The fish were fed a commercial feed at different feeding rates from 1.0 to $2.5 \%$ (with 0 . $5 \%$ increments) of body wet weight per day (w/day) at $23.1 \pm 1.1^{\circ} \mathrm{C}$. Each feeding rate was administered to groups of 20 fish. Growth rate, as measured by the percent body weight increase, and condition factor increased with increasing ration. Feed efficiency was better at $1.5 \%$ ration. There was no difference in feed efficiency between fish fed 2.0 and $2.5 \%$ w/ day, under the applied meal programme. Based on the growth and feed efficiency data, optimum feeding rate was estimated to be $1.22 \% \mathrm{w} /$ day.
\end{abstract}

\section{INTRODUCTION}

Food intake is the major limiting biotic factor affecting growth in fishes (Brett, 1979). Other abiotic and biotic factors may also affect growth directly or indirectly by acting upon feeding and metabolism (Phillips, 1972 ; Elliot, 1982 ; Brett and Groves, 1979 ; Brett, 1979). The accurate knowledge of the relation between growth and ration is a prerequisite for the determination of the lowest production costs. Determining optimum feed rations should contribute to improving the feasibility and economics of commercial fish units, by better feed utilization and reducing feed waste.

The experiment reported in this paper examined the effects of restricted feeding, under different feeding frequency patterns, on growth, food utilization and body form in silver sea bream, under laboratory conditions.

\section{MATERIALS AND METHODS}

Fifteen-month-old silver sea bream, Sparus sarba, which had been produced at the Fishery Research Laboratory of Kyushu University from the same batch of eggs, were used for this study. On August 30, 1993, fish of uniform size were selected from a larger population, starved for 24 hours, and then four groups (named A, B, C and D) each of 20 individuals established. Body weights of the fish were measured to the nearest $0.01 \mathrm{~g}$, and then each group was transferred into an indoor polycarbonate circular tank with a capacity of 5001 . The weights of the four experimental groups

* Contribution from Fish. Res. Lab., Kyushu University, No. 187.

Studies on the Propagation and Rearing of the Silver Sea Bream-III 
Teble 1. Daily meal programme for the silver sea bream.

\begin{tabular}{lllll}
\hline Group & Number of meals & Time & Ration per meal $(\%$ bw) Daily ration $(\%$ bw) \\
A & 1 & 10.00 & 1.0 & 1.0 \\
B & 2 & 10.00 and 17.30 & 1.0 and 0.5 & 1.5 \\
c & 3 & $10.00,15.00$ and 17.30 & $1.0,0.5$ and 0.5 & 2.0 \\
D & 4 & $10.00,12.30,15.00$ and 17.30 & $1.0,0.5,0.5$ and 0.5 & 2.5 \\
\hline
\end{tabular}

did not differ significantly $(\mathrm{P}>0.01)$.

The duration of the experiment was 40 days of which 35 were feeding days. A continuous flow of fresh sand-filtered sea water was supplied to the tanks at a rate of about $3 \mathrm{l} / \mathrm{min}$. Fish were reared under ambient water temperature conditions. Water temperature was monitored to the nearest $0.1^{\circ} \mathrm{C}$. Dissolved oxygen was maintained close to saturation by aerating the tanks with compressed air using air stones. There were four different feeding patterns according to the programme described in Table 1. All feeding was carried out by the same person. The feed used were dry pellets produced by Mercian Co. Ltd., for the rearing of red sea bream, Pagrus major. At the end of the experiment the fish were starved for 24 hours and their body weights and total lengths recorded. Food intake $(f)$ was expressed as a percentage of body wet weight per day according to the formula :

$$
f=\frac{F}{1 / 2\left(W_{2}+W_{1}\right) t} \times 100
$$

where $F$ is the amount of food consumed $(\mathrm{g}), W_{1}$ and $W_{2}$ are the initial and final weights of the fish (g), and $t$ is the rearing period (days).

Growth of the fish was expressed in terms of increase in wet weight per day according to the formula :

$$
g=\underset{1 / 2\left(W_{2}+W_{1}\right) t}{W_{2}} \times 100
$$

The efficiency of food utilization was expressed as a gross conversion efficiency according to the formula :

$$
E_{g}=g / f
$$

Condition factors were calculated for each fish at the start and at the end of the experiment using the formula :

$$
K=\left(W / L^{3}\right) \times 100
$$

where $W$ is body wet weight $(\mathrm{g})$ and $L$ is total length $(\mathrm{cm})$. From the individual data the mean condition factor for each group of fish was estimated.

Analysis of variance (ANOVA) and Fisher's LSD tests at $1 \%$ significant level were used to test for significant differences in growth in weight, and in condition factor. 


\section{RESULTS}

The results of the study are summarized in Table 2. During the experiment the water temperature ranged between 21.3 and $24.8^{\circ} \mathrm{C}$, with a mean value of $23.1 \pm 1.1^{\circ} \mathrm{C}$. A weight gain was recorded for all fish irrespective of ration. Growth rate was found to increase with increasing ration. However, a $2.5 \%$ ration does not appear to be the maximum (i. e. that ration producing maximum growth); greater growth could be obtained by feeding the fish a larger ration.

The relationship between food intake and growth rate is shown in Fig. 1. Growth rate $(\mathrm{g}$ ) was plotted against food intake (f) and the data were found to be best suited to a parabolic plot. A second degree polynomial fits the curve of the figure :

$$
\mathrm{g}=-0.2598+1.1212 f-0.1778 f^{2}\left(r^{2}=0.996\right)
$$

where $\mathrm{g}=$ growth rate (\% body wet weight per day) and $f=$ food intake (\% body wet weight per day).

The optimum food ration can be characterized as that food ration that provides for the greatest growth for least intake, resulting in a maximum gross growth efficiency (Brett et al., 1969 ; Huisman, 1976 ; Brett, 1979). The optimum ration was estimated graphically at 1.217 (\% body wet weight/day) using the method described by Brett et al. (1969) ; a tangent from the origin passes through the point where the ratio of $\mathrm{g}$ to $f$ is maximal.

The feed conversion ratio was better at the $1.5 \%$ daily. This value is close to optimum ration $(1.22 \%)$. At higher ration levels, the conversion efficiency had a lower value.

Absolute growth differed significantly across the range of ration $(P<0.01)$. Fish

Teble 2. Effects of feeding levels on growth and food conversion efficiency of 15-month old fish, over a 40-day rearing period.

\begin{tabular}{|c|c|c|c|c|c|c|c|}
\hline Group & р $\quad N W_{1}$ & $W_{2}$ & $K_{2}$ & $F$ & $f$ & $g$ & $E_{q}$ \\
\hline A & $2086.91 \pm 4.79^{a}$ & $106.48 \pm 5.85^{\mathrm{d}}$ & $1.80 \pm 0.09^{\mathrm{cd}}$ & 608.30 & 0.786 & 0.506 & 0.645 \\
\hline B & $2085.63 \pm 5.22 ”$ & $117.58 \pm 8.38^{c}$ & $1.85 \pm 0.09^{b c}$ & 912.45 & 1.112 & 0.785 & 0.706 \\
\hline $\mathrm{C}$ & $86.58 \pm 4.14 "$ & $126.39 \pm 7.82^{\mathrm{b}}$ & $1.91 \pm 0.09^{\mathrm{b}}$ & 1216.60 & 1.435 & 0.963 & 0.671 \\
\hline D & $86.53 \pm 3.33 "$ & $137.56 \pm 7.65 "$ & $2.00 \pm 0.09 "$ & 1520.75 & 1.696 & 1.139 & 0.671 \\
\hline
\end{tabular}

$N=$ number of fish

$W_{1}=$ initial mean body weight of fish $(\mathrm{g})$

$W_{2}=$ final mean body weight of fish (g)

$K_{2}=$ final mean condition factor of fish

$F=$ total amount of food consumed by the groups of fish (g)

$\mathrm{f}=$ food intake (\% body wet weight per day)

$g=$ growth rate (\% body wet weight per day)

$E_{g}=$ gross conversion efficiency

* Values that do not share the same letter superscripts are significantly different from each other $(P$ $<0.01)$. 


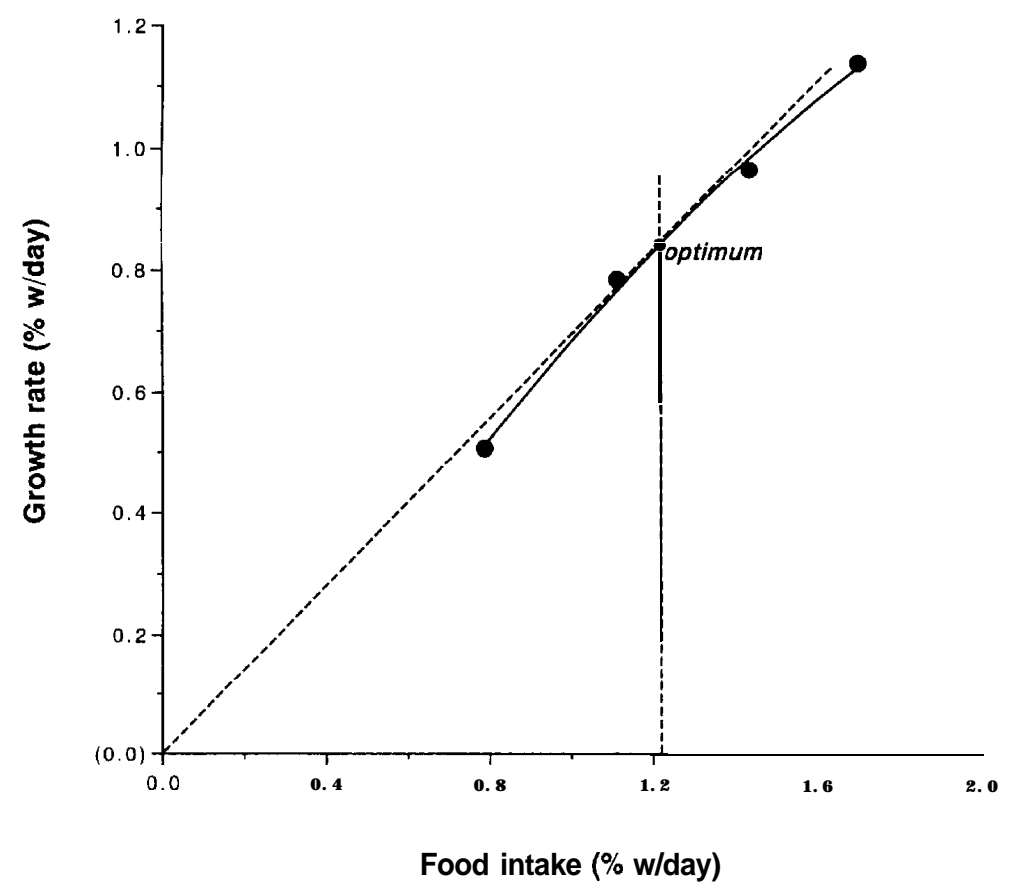

Fig. 1. The relationship between food intake $f$ and growth rate $g$ of 15 -month old silver sea bream.

exhibited curvilinear increase of the mean condition factor with ration (Fig. 2). Condition factor was significantly different among the four groups at the end of the experiment $(P<0.01)$ except between groups $\mathrm{C}$ and $\mathrm{D}(P>0.01)$. The relationship between condition factor and food intake can be expressed by the equation

$$
K=1.8270-0.1463 f+0.1455 f^{2} \quad\left(r^{2}=0.996\right)
$$

where $K$ is the condition factor and $f$ is the food intake (\% body wet weight/day).

\section{DISCUSSION}

The dependence of growth on ration size for silver sea bream shows the same kind of relationship that has been generally described for fish in review works (Brett, 1979 ; Brett and Groves, 1979). The position of optimum ration in the growth-ration curve may range from a relatively low to a relatively high ration according to species and environmental conditions, especially temperature (Brett and Groves, 1979). Estimates of the optimum ration for food conversion according to Brett et al. (1969), were derived by constructing the tangent of the curve in Fig. 1 for a line passing through the origin. 


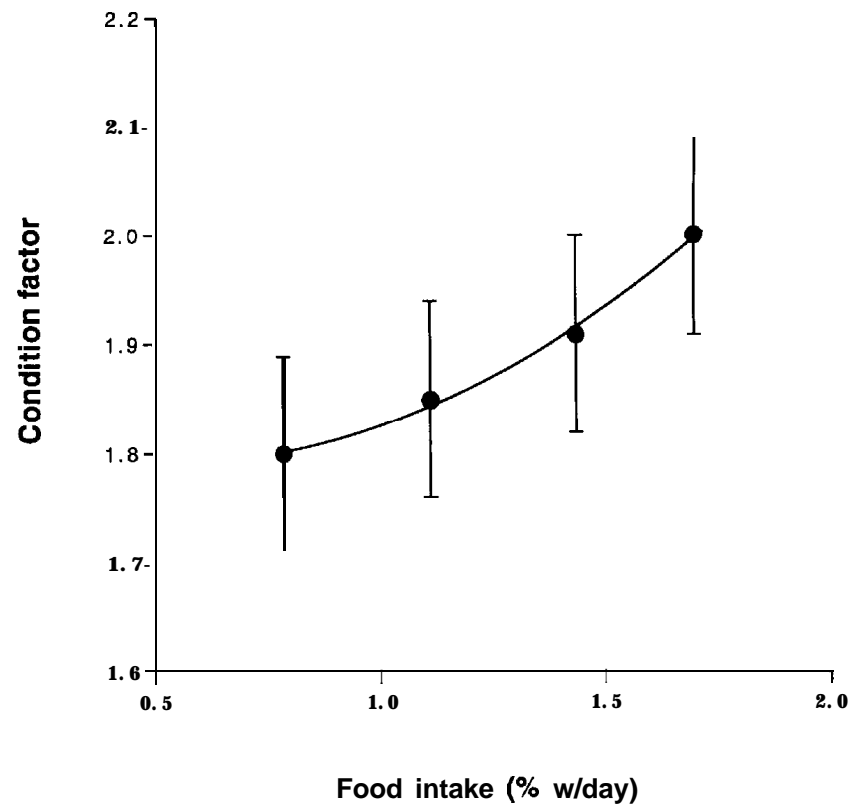

Fig. 2. The relationship between mean condition factor $\boldsymbol{K}$ ( \pm 2 S. E.) and food intake $f$ of silver sea bream.

The present feeding experiment showed that a feed ration of $1.22 \%$ per day was optimum for silver sea bream of about $86 \mathrm{~g}$ weight at $23.1 \pm 1.1^{\circ} \mathrm{C}$. For silver sea bream of $17 \mathrm{~g}$ body weight reared at $22.7 \pm 0.7^{\circ} \mathrm{C}$ and fed a similar dry feed, the optimum ration was estimated to be $1.15 \%$ per day (Mihelakakis and Kitajima, unpublished data) which is somewhat lower than the ration found in the present study.

Rations were restricted by reducing directly the "excess rations" on a weight specific basis. The slope of the curve in Fig. 1 progressively decreases to an asymptote corresponding to the maximum growth rate and the maximum ration. The asymptotic segment of the growth curve was not detected in this study because the maximum growth rate would only be attained at a higher feeding rate. The data indicate that the fish of group D could have eaten a larger daily ration.

Values of gross efficiency depend, in part, on the extent to which feeding rates approach the maximum feeding rates (Wurtsbaugh and Davis, 1977). Gross efficiency is highest at the optimum ration level and this is usually well below the maximum ration. It increases to a maximum with ration increase to some intermediate level and then declines with further increases (Warren and Davis, 1967 ; Williams and Caldwell, 1978 ; Huisman, 1976 ; Goolish and Adelman, 1984). The similar values of the food conversion efficiency in fish fed $2.0 \%$ and $2.5 \%$ (groups $\mathrm{C}$ and D respectively) ration levels at the end of the experimental period was probably due to different time intervals between the daily meals and a better utilization by fish of group D.

Condition factor is used to measure the variation from the expected weight of individual fish of the same length as indications of fatness (Le Cren, 1951). It was greater at each successively higher ration, and this is consistent with the report that 
well fed fish will have a higher condition factor than fish of the same length maintained on a lower plane of nutrition (Piper et al., 1986).

\section{REFERENCES}

Brett, J. R. 1979 Environmental factors and growth. In "Fish Physiology", Vol. VIII, ed. by W. S. Hoar, D. J. Randall and J. R. Brett, Academic Press, New York, San Francisco, London, pp. 599 $-675$

Brett, J. R. and T. D. D. Groves 1979 Physiological energetics. In "Fish Physiology" Vol. VIII, ed. by W. S. Hoar, D. J. Randall and J. R. Brett, Academic Press, New York, San Francisco, London, pp. $279-352$

Brett, J. R., J. E. Shelbourn, and C. T. Shoop 1969 Growth rate and body composition of fingerling sockeye salmon, Oncorhynchus nerka, in relation to temperature and ration size. J. Fish. Res. Board Can., 26 :2363-2394

Elliott, J. M. 1982 The effects of temperature and ration size on the growth and energetics of salmonids in captivity. Comp. Biochem. Physiol., $73: 81-91$

Goolish, E. M. and I. R. Adelman 1984 Effects of ration size and temperature on the growth of juvenile common carp (Cyprinus carpio L.). Aquaculture, $36: 27-35$

Huisman, E. A. 1976 Food conversion efficiencies at maintenance and production levels for carp, Cyprinus carpio L., and rainbow trout, Salmo gairdneri Richardson. Aquaculture, 9:259-273

Le Cren, E. D. 1951 The length-weight relationship and seasonal cycle in gonad weight and condition in the perch (Perca fluviatilis).J. Anim. Ecol., $20: 201-219$

Phillips Jr, A. M. 1972 Calorie and energy requirement. In "Fish nutrition" ed. by J. E. Halver, Academic Press, New York and London, pp. 1-28

Piper, R. G., I. B. McElwain, L. E. Orme, J. P. McCraren, L. G. Fowler and J. R. Leonard 1986 Fish Hatchery Management. Dept. of the Interior, U. S. Fish and Wildlife Service, Washington, DC, pp. 517

Warren, C. E. and G. E. Davis 1967 Laboratory studies on the feeding, bioenergetics, and growth of fish. In "The biological basis of freshwater fish production", ed. by S. D. Gerking, Blackwell, Oxford, pp. 175-214

Williams, S. F. and R. S. Caldwell 1978 Growth, food conversion and survival of O-group English sole (Parophrys vetulus Girard) at five temperatures and five rations. Aquaculture, 15 : 129-139

Wurtsbaugh, W. A. and G. E. Davis 1977 Effects of temperature and ration level on the growth and food conversion efficiency of Salmo gairdnen, Richardson. J. Fish. Biol., 11 : 87-98 